\title{
Ubidecarenone Quantification in Food Supplements A new HPLC method
}

\author{
VERONICA ISABELA CRACIUN ${ }^{2 *}$, FELICIA GABRIELA GLIGOR², ANCA MARIA JUNCAN², LUCA LIVIU RUS ${ }^{1,2}$, \\ CLAUDIU MORGOVAN ${ }^{2}$ \\ 1Polisano Pharmaceuticals SA, 156 Alba Iulia Av., 550052, Sibiu, Romania \\ 'Lucian Blaga University of Sibiu, Faculty of Medicine, Preclinical Department, Pharmacy Specialization, 2A Lucian Blaga Str., \\ 550169, Sibiu, Romania
}

\begin{abstract}
Coenzyme Q10 has a powerful antioxidant effect because it protects cells against free radicals and plays an important role in metabolism. Although controversial some preliminary evidence suggests that Coenzyme Q10 can help prevent or treat treatment of diseases of the cardiovascular and musculoskeletal systems and liver problems. Age increase and medical conditions are associated with lower Coenzyme Q10. There are evidences that diet supplementation with supplements containing Coenzyme Q10 may be beneficial. This paper aims to develop an HPLC method for identifying and dosing Ubidecarenone in food supplements. Using this technique, several supplements containing varying Ubidecarenone, ranging from 76 to $103 \%$ of the stated amount per dosage form were tested.
\end{abstract}

Keywords: Ubidecarenone, HPLC method, dietary supplements

According to WHO Constitution, Governments are responsible for the citizen's health condition and the highest level of health is a fundamental right of every human being [1]. At the moment, severe pathologies (cancer, cardiovascular, metabolic, neurodegenerative, dermatologic or infectious diseases etc.) have worldwide a higher prevalence [2-4]. Fortunately, today, people are more educated and have many information sources in order to improve their health status. Using differenthealth products, people incline to obtain a better life quality or to prevent the risk of illness [2]. On the other hand, many consumers prefer natural, even organic products. In this respect, the responsible manufacturers have established themselves to market safety and efficacy products [5-8]. Also, they use more and more natural and simple, common known molecules, whether we refer to dietary supplements, cosmetics, medical devices and even to medicines (coenzyme Q10, Aloe vera, resveratrol, hyaluronic acid, lipoic acid, omega-3, Ginkgo biloba, Echinacea, Hypericum, Silybum marianum etc.) $[2,9,10]$. Additionally, producers use modern technologies to prepare pharmaceutical products and also, they have to elaborate and respectstrict rules to assure the product's quality. It isn't neglected the analytical quality control which is made during production and to the end of process and also based on advanced techniques [11-15].

Coenzyme Q10 (CoQ10 or Ubidecarenone) is a biologically active compound that is similar in chemical structure to menaquinones (Vitamin K2). Part of a family of quinone compounds known as coenzyme Q, CoQ10 is characterized by a quinone ring attached to a repeating series of side-chain isoprene units (Fig. 1).<smiles>CCC(C)=CCC1=C(C)C(=O)C(OC)=C(OC)C1=O</smiles>

Fig. 1. Chemical structure of Ubidecarenone
The number of isoprene units is denoted by the coenzyme- $X$ designation. In the case of CoQ10, there are 10 repeating isoprene units $[16,17]$.

CoQ10 is synthesized in mitochondria by a set of at least 12 proteins that form a multiprotein complex. The efficiency of coenzymeQ10 depends on the level of glutathione in the body [18]. Beside the antioxidant capacity of CoQ10, other beneficial effects include:

-the prevention of lipid peroxidation initiation in plasma membranes

-the improvement of antihypertensive functions

-the prevention of low-density lipoprotein oxidation

-thetreatment of migraine headache

-the treatment of cardiovascular diseases

-the treatment of neurodegenerative disease (Parkinson's Disease) [19-24].

Coenzyme Q10 has multiple uses due to its antioxidant role. It is used in dietary supplements in combination with other active principles, in anti-aging cosmetics, in improving the blood cardioplegia solution to compensate its flawsand to offer maximum security in case of myocardialprotection [25-32].

To estimate the Ubidecarenone content from foods and foods supplements a lot of methods were developed over the years. Many papers were published describing quantitative determination of Ubidecarenone in different matrices (pharmaceutical dosage forms, biological fluids, tissues, foodstuff, etc): HPLC with different detection [3243], zero-order and second-order derivative spectrophotometry [44, 45], voltammetry [46], ${ }^{1} \mathrm{H}$ NMR spectroscopy [47], FT-NIR spectroscopy [48] and X-ray diffraction [49].

High performance liquid chromatography is a modern method used to assay a lot of active principles in food supplementsand also to determine the content of active substances in drug products $[50,51]$. In this study a HPLC method for Ubidecarenone assay was developed.

\section{Experimental part}

Materials, reagents and standards

For the assay of Ubidecarenone there were analysed five food supplements. A large number of $\mathrm{COQ} 10$ products are available on the market. These products are soft gel

\footnotetext{
* email: isabela.craciun@polisanopharmaceuticals.ro
} 
encapsulated in a gelatine shell. A small number of products use 2-piece gelatine hard shells or CoQ10 in a tablet formulation. The products analysed were soft gel capsules and hard gelatine capsules purchased from Romanian market. The samples were coded as follows:

PBO0A - is presented as hard gelatine capsules containing $10 \mathrm{mg}$ of Q10 coenzyme/cps., $128.25 \mathrm{mg}$ proantocyanidines from grape seeds extract, $800 \mu \mathrm{g}$ retinol, $8 \mathrm{mg}$ Tocopherol and $50 \mathrm{mg} / \mathrm{cps}$. of selenium;

-PBOOB - is presented as soft gelatine capsules containing $60 \mathrm{mg} / \mathrm{cps}$. of Q10 coenzyme, $150 \mathrm{mg} / \mathrm{cps}$. of magnesium, $15 \mathrm{mg} / \mathrm{cps}$. of Resveratrol and $3 \mathrm{mg} / \mathrm{cps}$. of pyridoxine;
-PBO0C - is presented as hard gelatine capsules containing $60 \mathrm{mg}$ of Q10 coenzyme/cps and $95 \mathrm{mg}$ proanthocyanidines from grape seeds/cps.and $50 \mathrm{mg}$ Resveratrol /cps.;

-PBO0D - is presented as soft gelatine capsules containing $60 \mathrm{mg}$ of Q10 coenzyme/cps.;

-PBOOE - is presented as hard capsules containing 10 $\mathrm{mg}$ of Q10 coenzyme/cps. and $300 \mathrm{mg} / \mathrm{cps}$. lipoic acid.

\section{Sample and standard solutions preparation}

The average mass was performed on 20 capsules from each product. The sample solution for hard and soft gelatine capsules was prepared using $25 \mathrm{mg}$ of content from 20
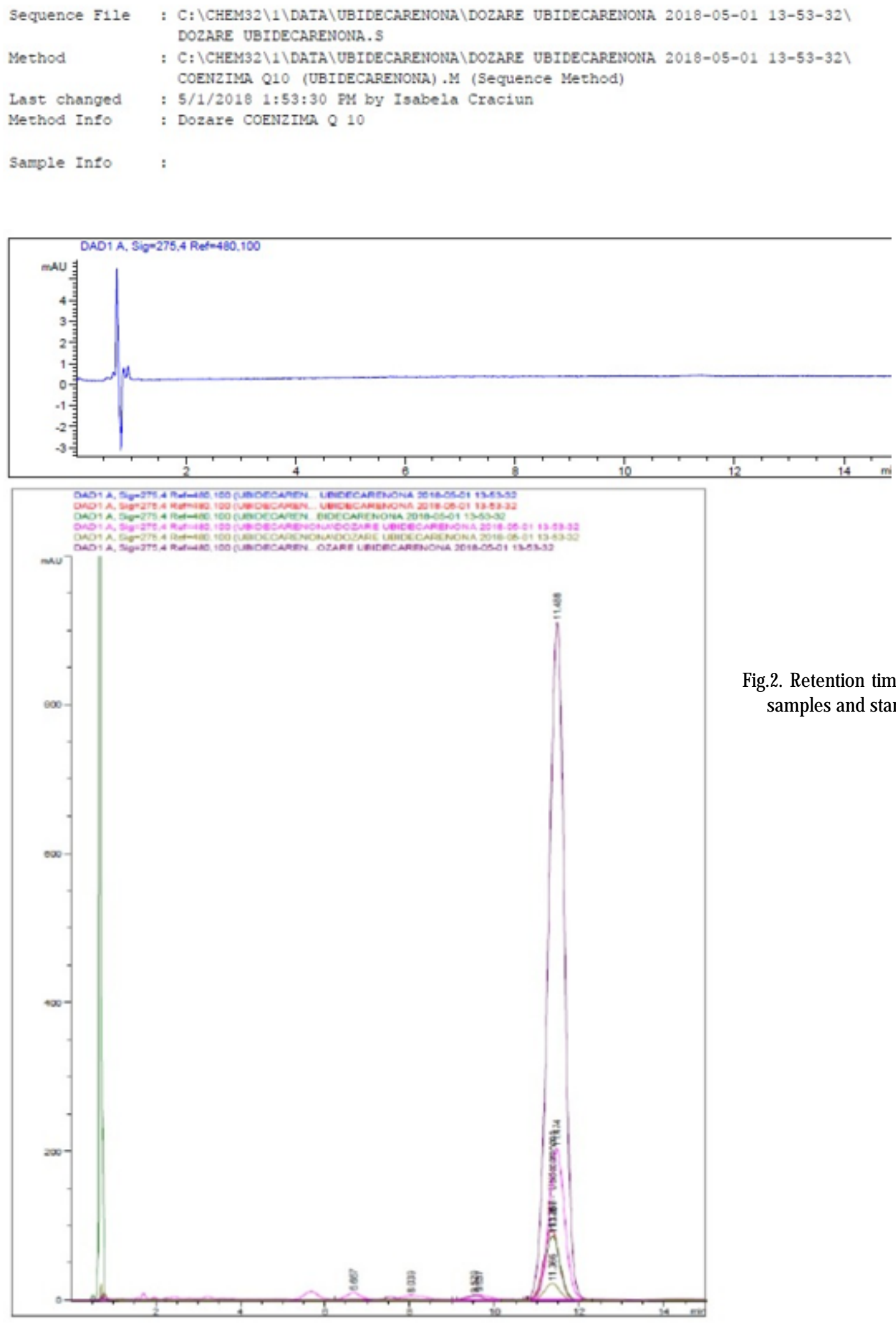

Fig.2. Retention times of Ubidecarenone for samples and standard chromatograms 


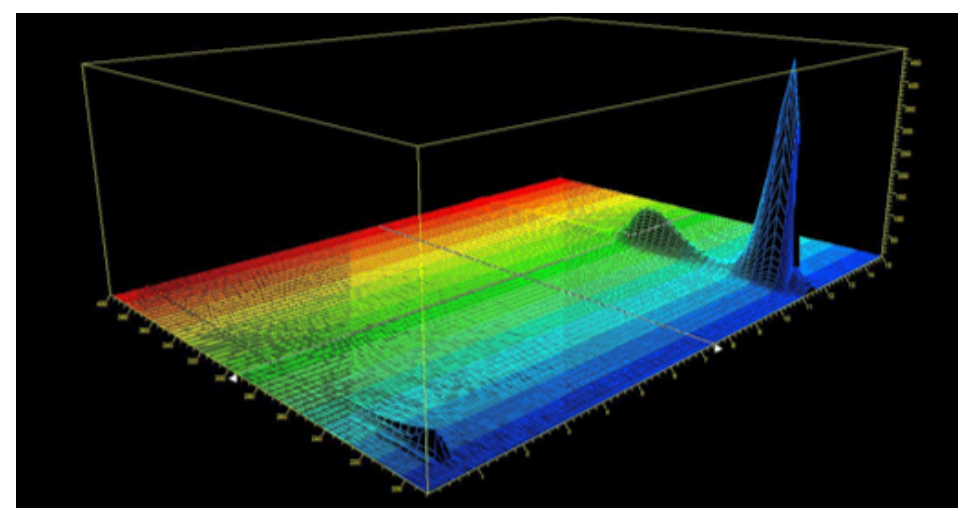

Fig.3. 3D chromatogram of Ubidecarenone

capsules which was transferredinto a $20 \mathrm{~mL}$ volumetric flask and dissolved with ethanolon a Julabo TW 12 water bath at $50^{\circ} \mathrm{C}$ for $2 \mathrm{~min}$.

The standard solution was prepared in same manner using $5 \mathrm{mg}$ of Ubidecarenone CRS (99.6\%) from EDQM.The standard and sample solutions were previously filtered using 0.45 micron filters before injection.

The standard solution was injected six times and each sample solution was prepared in triplicate and injected once. The solvents used for solutions and for mobile phase preparation were of HPLC analytical purity from VWR.

\section{Equipment and chromatographic conditions}

The identification and assay of Ubidecarenone was performed using a HPLC method developedon basis of the European Pharmacopoeia.

The separation was achieved using a Zorbax SB-C18, $150 \times 4.6 \mathrm{~mm}, 100 \AA$, at $25^{\circ} \mathrm{C}$ temperature with an isocratic mixture of ethanol and methanol in the ratio of $40: 60 \% \mathrm{~V} /$ $V$ at a flow rate of $2 \mathrm{~mL} / \mathrm{min}$ and UV detection at $275 \mathrm{~nm}$. The volume of injection used was $20 \mu \mathrm{L}$. The retention time of Ubidecarenone was around 11 minutes.

Chromatographic separation was performed by HPLC using an Agilent 1200 HPLC system consisting of a quaternary pump, degassing device, autosampler,

Table1

SYSTEM SUITABILITY PARAMETERS OF UBIDECARENONE PEAK

\begin{tabular}{|c|c|}
\hline Parameters & Obtained values \\
\hline $\begin{array}{c}\text { Theoretical plates/column, } \\
\text { halfwidth method }\end{array}$ & 4465 \\
\hline USP Tailing factor & 1.006 \\
\hline Symmetry & 0.999 \\
\hline
\end{tabular}

Table2

UBIDECARENONE CONTENT OF FOOD SUPPLEMENTS

\begin{tabular}{|l|l|l|}
\hline Sample & CoQ10 claimed & CoQ10 (HPLC \\
content, mg/cps. & $\begin{array}{l}\text { method), \% of } \\
\text { labeled content }\end{array}$ \\
\hline PBO0A & 10 & 97 \\
\hline PBO0B & 60 & 76 \\
\hline PBO0C & 60 & 103 \\
\hline PBO0D & 60 & 97 \\
\hline PBO0E & 10 & 95 \\
\hline
\end{tabular}

diode array detector (PDA), and Agilent ChemStation software.

\section{Results and discussions}

Identification of Ubidecarenone in sample solutions was made by comparison of retention times and by spectral data of PDA with those obtained for the standard solution as is shown in Fig. 2. and Fig. 3.

The results of system suitability parameters such as tailing factor, symmetry and number of theor etical plates are indicated satisfactory resylts and tabulated in the table 1.

Quantification of Ubidecarenone in each product was performed on the basis of the external standard method against average of 6 peak areas of standard solution chromatogram. The results are shown in Table 2.

The content of Ubidecarenone in the analyzed samples was found between 76 and $103 \%$ from the claimed label potency. According to this data, the content of Ubidecarenone in samples PBO0A, PBO0C, PBO0D and PBO0E was close to the label content and in the sample PBO0B the content of Ubidecarenone was less than claimed.

The precision of Ubidecarenone was determined as the variation coefficient (RSD \%) for six successive injections of the standard solution which was 0.032 .

\section{Conclusions}

An adequate method was developed for the assay of Ubidecarenone in raw materials and finished products as soft gels and hard gelatin capsules. The proposed method is accurate, simple, costeffective and less time consuming.

Acknowledgement: The authors wish to thank Polisano Pharmaceuticals SA for its generous contributions of research facilities and resources.

\section{References}

1.*** WHO, Basic Documents, Forty-fifth edition, Supplement, October 2006.

2.MORGOVAN, C., GHIBU, S., JUNCAN, A. M., RUS, L. L., BUTUCA, A., VONICA, L., MUNTEAN, A., MOS, L., GLIGOR, F., OLAH, N. K., Farmacia, 67, 3, 2019, p. 537.

3.UNGUREANU, A., RUS, L. L., GLIGOR, F. G., LAZAROAIE, A., PRODAN, L., ROMAN-FILIP, C., Farmacia, 64, 4, 2016, p. 507.

4.GHIBU, S, DECEA, N., MORGOVAN, C., MOGOSAN, C.,Farmacia, 61 , 2, 2013, p. 420.

5.JUNCAN, A. M., RUS, L. L., CRACIUN, V. I., VONICA TINCU, A. L., MORGOVAN, C., Rev. Chim. (Bucharest), 70, no. 7, 2019, p. 2429. 6.MUNTEAN, A. C., JUNCAN, A. M., MOISA, D. G., VONICA, A. L., RUS, L. L., MORGOVAN, C., GLIGOR, F. G. BUTUCA, A., STANILA, A., Mat. Plast., 56, no. 2, 2019, p. 360.

7.JUNCAN, A. M., Mat. Plast., 55, no. 4, 2018, p. 644.

8.JUNCAN, A. M., RUS, L. L., Mat. Plast., 55, no. 3, 2018, p. 426. 
9.CRACIUN, V. I., GLIGOR, F. G., JUNCAN, A. M., CHIS, A. A., RUS., L. L., Rev. Chim. (Bucharest), 70, no. no. 9, 2019, p. 3202.

10.J UNCAN, A. M., HORGA, E. C., HODISAN, T., Studia UBB Chemia, 56, 2, 2011, p. 195.

11.DANCIU, C., BIRIS, M., BOGLARKA, B., CSANYI, E., ZINUCA PAVEL, I., POP, G., SOICA,C.,CEUTA,L., NITAL.,MORGOVAN,C., STOIAND.,Rev. Chim. (Bucharest), 66, no. 7, 2015, p. 1038.

12.TITA, B., MORGOVAN, C., TITA, D., NEAG, T. A., Rev. Chim. (Bucharest), 67, no.1 2016, p. 38.

13.JUNCAN, A. M., RUS, L. L., GLIGOR, F. G., MORGOVAN, C, Rev. Chim. (Bucharest), 70, no. 2, 2019, p. 555.

14.AVRAM, N., HEGHES, S. C., RUS, L. L., JUNCAN, A. M., RUS, L. M., FILIP, L., FILIP ROMAN, C., Rev. Chim. (Bucharest), 70, no.2,2019, p. 487.

15.J UNCAN, A. M., MORGOVAN, C., RUS, L. L., Rev. Chim. (Bucharest), 70, no. 8, 2019, p. 2764.

16.LUNETTA, S., ROMAN, M., J. AOAC Int., 91, 4, 2008, p. 702.

17.ACOSTA, M. J., VAZQUEZ FONSECA, L., DESBATS, M. A., CERQUA, C., ZORDAN, R., TREVISSON, E., SALVIATI, L., Biochim. Biophys. Acta., 1857, 8, 2016, p. 1079.

18.MACOVEI, L. A., DEBITA, M., ILIE, M., MOISEI, M., CHISCOP, I., CARDONEANU, A., REZUS, E.,Rev. Chim. (Bucharest), 66, 10, 2015, p. 1645.

19.ALLEVA, R., SCARAARMUCCI, A., MANTERA, F., BOMPANDRE, S., LEONI, L., LINARRO, G. P., Mol Aspects Med., 18, 1997, p.221.

20.RAITAKARI, O. T., MCCREDIE, R. J., WITTING, P., GRIFFITHS, K. A., LETTER, J., SULLIVAN, D., STOCKER, R., CELERMAJER, D. S., Free Radic. Biol. Med., 28, 2000, p.1100.

21.LANGSJ OEN, P., LANGSJ OEN, A., WILLIS, R., FOLKERS, K., Mol Aspects Med., 15, 1994, p. 265.

22.ROZEN, T. D., Cephalalgia, 22, 2002, p.137.

23.MULLER, T., BUTTNER, T., GHOLIPOUR, A. F., KUHN, W., Neurosci Lett., 341, 2003, p. 201.

24.KENDLER, B. S., Prog. Cardiovasc. Nurs., 12, 1997, p. 3.

25.FURNICA, C., CHISTOL, R.O., LEON CONSTANTIN, M. M., COBZARU, R. G., RIPA, C. V., BULGARU ILIESCU, D., TINICA, G., Rev. Chim. (Bucharest), 67, no. 7, 2016, p. 1271.

26.HOJEROVÁ, J., Ceska Slov Farm., 49, 3, 2000, p. 23.

27.BANACHA, M., SERBAN, C., URSONIUC, S., RYSZ, J., MUNTNER, P., TOTH, P. P., JONES, S. R., RIZZO, M., GLASSER, S. P., WATTS, G. F., BLUMENTHAL, R. S., LIP, G. Y. H., MIKHAILIDIS, D. P., SAHEBKAR, A., Pharmacol Res, 99, 2015, p. 329.

28.DINICOLANTONIO, J. J., BHUTANI, J., MCCARTY, M. F., O'KEEFE, J. H., Open Heart, 2, 1, 2015, p. e000326.
29.MAZIDI, M., KENGNE, A. P., BANACH, M., Pharmacol Res, 128, 2018, p. 130.

30.MEHRABANI, S., ASKARI, G., MIRAGHAJANI, M., TAVAKOLY, R., ARAB, A., Complement Ther Med, 43, 2019, p. 181.

31.XU, Y, LIU, J, HAN, E., WANG, Y., GAO, J., BMJ Open, 9, 5, 2019, p. e029053.

32.TANG, P. H., MILES, M. V., STEELE, P., DAVIDSON, B. S., GERAGHTY, S. R., MORROW, A. L., Biomed Chromatogr, 20, 2006, p. 1336.

33.XIA, S., XU, S., J Sci Food Agric, 86, 13, 2006, p. 2119.

34.LI. K., SHI, Y., CHEN, S., LI, W., SHANG, X., HUANG, Y., Biomed Chromatogr, 20, 2006, p. 1082.

35.RODRIGUEZ-ESTRADA, M. T., POERIO, A., MANDRIOLI, M., LERCKER, G., TRINCHERO, A., TOSI, M. R., TUGNOLI, V., Anal Biochem, 357, 1, 2006, p. 150.

36.RODRÍGUEZ-ACUÒA, R., BRENNE, E., LACOSTE, F., 56, 2008, p. 6241.

37.TRIPODI, V., FLOR, S., CONTIN, M., LUCANGIOLI, S., J Liq Chromatogr Relat Technol , 32, 6, 2009, p. 860.

38.GLEIZE, B., STEIB, M., ANDRÉ, M., REBOUL, E., Food Chem, 134, 2012, p. 2560.

39.ITKONEN, O., SOUMALAINEN, A., TURPEINEN, U., Clin Chem, 59, 8, 2013, p.1260.

40.MANZI, P., DURAZZO, A., Dairy Sci. \& Technol., 95, 4, 2015, p. 533. 41.MUHEEM, A., SHAKEEL, F., ZAFAR, S., JAHANGIR, M. A., WARSI, M. H., JAIN, G. K., AHMAD, F. J., Braz. J. Pharm. Sci., 53, 4, 2017, p. e17293.

42.SCHOU-PEDERSEN, A. M. V., SCHEMETH, D., LYKKESFELDT, J., Antioxidants, 8, 8, 2019, p. 253.

43.BAO, K., ZHANG, C., XIE, S., FENG, G., LIAO, S., CAI, L., HE, J., GUO, Y., JIANG, C., Molecules, 24, 9, 2019, p. 1767.

44.KARPINSKA, J., MIKOfUÇ, B., PITROWSKA-J ASTRZESKA, J., J Pharm Biomed Anal, 17, 1998, p. 1345.

45.KARPIÑSKA, J., MULARCZYK, B., Spectrochim. Acta A, 60, 2004, p. 2189.

46.MICHALKIEWICZ, S., Bioelectrochemistry, 73, 2008, p. 30.

47.MONAKHOVA, Y. B., RUGE, I., KUBALLA, T., LERCH, C., LACHENMEIER, D. W., Int. J. Vitam. Nutr. Res., 83, 1, 2013, p. 67.

48.RACZ, A., VASS, A., HEBERGER, K., FODOR, M., Anal Bioanal Chem, 407, 10, 2015, p. 2887.

49.BUCIUMAN, C., MARIAN, E., TITA, B., JURCA, T., CHIS, A., VICAS, L., Rev. Chim.(Bucharest), 69, no. 11, 2018, p. 3221.

50.HEGHES, S. C., RUS, L. M., RUS, L. L., BOJ ITA, M. T., IUGA, C. A., Farmacia, 65, 5, 2017, p. 755.

51.MOISEI, A., TOTAN, A., GLIGOR, F. G., CRACIUN, I., TODORAN, N., CHIS, A. A., POPA, D. E., Farmacia, 64, 4, 2016, p. 612.

$\overline{\text { Manuscript received: } 21.06 .2018}$ 